\title{
'REASONS OF STATE FOR ANY AUTHOR' COMMON SENSE, TRANSLATION, AND THE INTERNATIONAL REPUBLIC OF LETTERS. ${ }^{1}$
}

\author{
José María Pérez Fernández \\ University of Granada
}

\begin{abstract}
This chapter will focus on several case studies that illustrate the nature of the material and intellectual networks of authors, editors, publishers and translators who laid the foundations of the international republic of letters as a virtual third space between the inveterate system of aristocratic patronage and the growing mass of urban consumers. It shall first trace the evolution of the new conditions within the book market and the concerns they raised among authors through a comparison of some texts produced in England by Gabriel Harvey ( $c a$. 1552-1631) and his circles with the pragmatic political vocabulary displayed a generation later by Antonio López de Vega (ca. 1586-1655) in Spain. Whereas Harvey and López de Vega shared the influence of international Ciceronianism, one of the most remarkable differences between them lies in the shift from the moral concerns of sixteenth-century humanism to the more pragmatic and disenchanted views expressed in the languages of neostoicism and Tacitism. The second part of this chapter will then examine the consequences deriving from the development of a new international market for the mass consumption of cultural products, chiefly printed matter, but also the public commercial stage. Situated between its status as a new form of mass entertainment in thriving urban milieus and its canonization as printed goods through the publication of the most successful among these plays, the public stage constitutes a uniquely dynamic phenomenon that illustrates these literary, intellectual and material developments.

The international republic of letters stood as a heterogeneous and adiaphoric public space that grew out of these manifold tensions. The interdisciplinary discourse that created and regulated it was woven with the languages of moral philosophy, politics and theology, as well as the vocabulary of traditional literary doctrine. Its agents were-to use an expression coined by Antonio López de Vega - men of understanding engaged in a transnational conversation sustained by common language and common sense. This pragmatic and consensual view of language and knowledge resulted from the intersection between the new trends of cultural and literary mercantilism, on the one hand, and more traditional aesthetic theories founded upon the discourse of what David Summers has called Renaissance Naturalism, on the other.
\end{abstract}

1 This is the pre-peer-review, author's version of a book chapter that will be published in $A$ Maturing Market. The Iberian World in the First Half of the Seventeenth Century, edited by Alexander S. Wilkinson and Alejandra Ulla Lorenzo (forthcoming in Brill, 2017). The author is grateful to the editors and the publisher for permission to issue this version. 


\section{A Transnational Third Space}

During the sixteenth and early seventeenth centuries prefaces and dedicatory epistles frequently insisted on the subjective nature of the moral judgment that readers should wield when approaching their texts. Transferring responsibility to each individual reader relieved authors, translators and publishers from the task of producing a more explicitly moralistic text, which in turn made these texts more appealing to the wider and far more varied audiences that could now gain access to them.

These paratexts responded to the pressures of censorship, but also to changes in the material conditions for the production and consumption of printed matter. The loss of social and intellectual prestige brought about by the easy and relatively inexpensive access to literary discourse facilitated by the commercial theatre and the mass-production of chapbooks, pamphlets and other affordable editions was a source of much anxiety among authors, who felt exposed and vulnerable in the face of what Alexandra Halasz has called the "structural change in the conditions of discursive production". ${ }^{2}$

The development of this market for cheap print encouraged more intellectually ambitious authors to target reading communities well beyond academic circles or the traditional networks of aristocratic patronage, but also distinct from the new mass of undiscerning urban consumers. This resulted in the creation of an ideal reader whose autonomous understanding and moral sense equipped him to appreciate the intellectual and aesthetic virtues of the volume in question. This reader could absorb the texts and their rhetoric properly through an enlarged and critically enhanced subjectivity endowed with the judicious capacity to take in the proper exempla - both positive and negative - displayed in the volumes. This phenomenon went hand in hand with the first hints at a theory of taste that could be used to legitimize a new kind of elite, a meritocracy of wit and ingenio.

Intellectual and political debate, and above all, competing religious doctrines gave momentum to the constant flow of printed matter that came out of

\footnotetext{
${ }^{2}$ Alexandra Halasz. The Marketplace of Print. Pamphlets and the Public Sphere in Early Modern England (Cambridge, UK: Cambridge University Press, 1997), 4. See also "The Creation of a European Book Market", in Andrew Pettegree, The Book in the Renaissance (New Haven and London: Yale University Press, 2010), 65-90. For cheap print and pamphlets, see the work of Joad Raymond, in particular his "Introduction: networks, communication, practice", in Joad Raymond, ed. News Networks in Seventeenth-Century Britain and Europe, London: Routledge, 2007), 1-18. On the Spanish book market, see Donald W. Cruickshank's “'Literature' and the Book Trade in Golden-Age Spain”, Modern Language Review, 73:4(1978), 799-824.
} 
the European presses. The intersection of theological controversy with private self-interest and business transactions led to the growth of a heterogeneous public sphere founded upon the concept of adiaphora. The actual import of this term when it came to trade and economic relations stemmed from the frequent obliteration of religious differences to prevent them from interfering with the flow of goods and capital. Adiaphora originated within classical stoicism to describe morally neutral actions. It was then introduced into the realm of theology to denote those aspects of doctrinal debate which did not substantially affect the key terms of the dispute. In a period of intense theological controversy, it naturally became an important intellectual tool for the pursuit of ecumenism. And it evolved until, as Gary Taylor has pointed out, "in the end indifference or disinterestedness was itself canonized as the most important social, cultural and intellectual virtue". ${ }^{3}$ With the ideal autonomous reader, adiaphora would also underpin the international republic of letters.

This chapter will focus on several case studies that illustrate the nature of the material and intellectual networks of authors, editors, publishers and translators who laid the foundations of this international republic of letters as a virtual third space between the inveterate system of aristocratic patronage and the growing mass of urban consumers. It shall first trace the evolution of the new conditions within the book market and the concerns they raised among authors through a comparison of some texts produced in England by Gabriel Harvey ( $c a$. 1552-1631) and his circles with the pragmatic political vocabulary displayed a generation later by Antonio López de Vega (ca. 1586-1655) in Spain. Whereas Harvey and López de Vega shared the influence of international Ciceronianism, one of the most remarkable differences between them lies in the shift from the moral concerns of sixteenth-century humanism to the more pragmatic and disenchanted views expressed in the languages of neostoicism and Tacitism. The second part of this chapter will then examine the consequences deriving from the development of a new international market for the mass consumption of cultural products, chiefly printed matter, but also the public commercial stage. Situated between its status as a new form of mass entertainment in thriving urban milieus and its canonization as printed goods through the publication of the most successful among these plays, the public stage constitutes a uniquely dynamic phenomenon that illustrates these literary, intellectual and material developments.

The international republic of letters stood as a heterogeneous and adiaphoric public space that grew out these manifold tensions. The

\footnotetext{
${ }^{3}$ See Gary Taylor, "The cultural politics of Maybe", in R. Dutton, A.G. Findlay \& R. Wilson, eds. Lancastrian Shakespeare: Theatre and Religion (Manchester, UK: Manchester University Press, 2003), 242-258, p. 255. See also G.R. Evans, "Sancta Indifferentia and Adiaphora. 'Holy Indifference' and 'Things Indifferent", Common Knowledge, 15:1(2009), 23-38, for a recent account of the origins of the term and its role in the religious disputes of the sixteenth and seventeenth centuries; see also Thomas F. Mayer, "Starkey and Melanchton on Adiaphora: A Critique of W. Gordon Zeeveld", The Sixteenth Century Journal vol. 11, no. 1 (1980), 39-50. A good survey can also be found in Bernard J. Verkamp. The Indifferent Mean: Diaphorism in the English Reformation to 1554, (Detroit: Wayne State U.P.), 1978.
} 
interdisciplinary discourse that created and regulated it was woven with the languages of moral philosophy, politics and theology, as well as the vocabulary of traditional literary doctrine. Its agents were-to use an expression coined by Antonio López de Vega-men of understanding engaged in a transnational conversation sustained by common language and common sense. This pragmatic and consensual view of language and knowledge resulted from the intersection between the new trends of cultural and literary mercantilism, on the one hand, and more traditional aesthetic theories founded upon the discourse of what David Summers has called Renaissance Naturalism, on the other. ${ }^{4}$

\section{II \\ Communication among Men of Understanding: Language and the Civic Order}

The Cambridge scholar Gabriel Harvey courted an elitist and learned audience with his works in Latin (Ciceronianus, 1577, or Rhetor, 1578) while trying to cater for the as yet select, but nevertheless more numerous, readers in the vernacular with his works in English. Pursuing prestige among the university wits, and the international elite of Neo-Latin culture, he could not fail to express his disdain for the book market and the multitudes that constantly demanded editorial novelty. The anxiety stirred by his desire to inscribe himself within the aristocracy of wit, his pursuit of fame, and the unavoidable plunge into the bookstalls of Saint Paul's Churchyard, frequented by all sorts of people, is patently acknowledged in one of his letters to Edmund Spenser. ${ }^{5}$

Harvey declares here that "in publishing" his poems "abroad in print", he has been exposed "to the use, or rather, abuse, of others" (p. 112), and his works have become "prostituted devices" (p. 119). He anxiously acknowledges that the printed poems are already irretrievable, and consequently "they must needs in all haste no remedye be sett to sale in Bartholomewe and Sturbridge fayer" (p. 113); "how will my right worshipfull and thrise venerable masters of Cambridge", he frets, "scorne at the matter?" (p. 114). Harvey imagines his printed material for sale at the bookstalls, ventriloquizing the voice of the bookseller hustling his goods before the prospective buyer:

I pray you will you see any freshe new bookes? Looke, I beseeche you, for your loove and buie for your moonye. Let me yet borrowe on cracked

\footnotetext{
${ }^{4}$ David Summers, The Judgment of Sense. Renaissance Naturalism and the Rise of Aesthetics (Cambridge University Press, 1987).

5 "To his very unfrendly frende that procurid the edition of his so slender and extemporall devises". It was published by Edward John Long Scott in 1884 (Letter-Book of Gabriel Harvey, 1573-80, Camden Society). The edition consulted here is The Works of Gabriel Harvey, vol. I, ed. Alexander B. Grosart, London, The Huth Library, 1884.
} 
groate of your purse for this same span new pamflett. I wisse he is a University man that made it, and yea, highlye commended unto me for a greate scholler. I marry, good syr, as yu says, so it shoulde appeare in deede by his greate worke... will iij ${ }^{\mathrm{d}}$ fetch it? (p. 113)

Gabriel Harvey illustrates the paradoxes and pitfalls incurred in the simultaneous pursuit of a language common to all that can gather within the public sphere if not a majority at least a sufficiently large group of individuals endowed with the natural potential for a discerning wit, on one hand, and the creation of a new aristocracy of the mind, on the other. Harvey's strategy was to push for a via media, not just in terms of form and content, but in terms of attitude, above all when it came to debates in the public arena. This defense of moderation is inseparable from the adoption of a style moulded by reason-what Lisa Jardine has described as "the art of reasonable discoursing". 6

The trope that Harvey used to argue in favour of harmony was that of the variously proportioned body parts - a common figure in classical handbooks for rhetorical balance in orations, and even more frequent in the well-established metaphor of the body politic. In one of his published letters, addressed to "the same fauorable, or indifferent, reader", he declared that his intention was to see

'Learning flourish: Vertue prosper: the good proceede from better to better: the bad amend: the Body cherish the members: the Members tender the body: all generally maintaine Concord with all: every one particularly nurrish accord with every one ${ }^{7}$

In his famous public controversy with Thomas Nashe, Harvey contrasts his opponent's 'overreaching' style with the kind of moderation and temperance

\footnotetext{
${ }^{6}$ See Lisa Jardine, "The Place of Dialectic Teaching in Sixteenth-Century Cambridge", Studies in the Renaissance 21(1974): 31-62, 62. In the same article (p. 50), Jardine lists Valla's Elegantiae and Erasmus's Apophthegmata among the manuals of style that took the place of more traditional rhetoric in the education of students at the University of Cambridge. Another handbook frequently used in Harvey's Cambridge was Rudolph Agricola's De invention dialectica libri tres, in which dialectic is described as "the practical study of the ways in which we communicate knowledge to others" (Jardine, 1974, p. 51); according to Jardine, "Agricola's emphasis on invention, like Cicero's before him, signals an approach to dialectic which aims at extracting from Aristotelian logic the bare minimum of formal apparatus, and building on this a largely descriptive study of language use" (Jardine, 1974, p. 51; italics are mine). For more details on this aspect of Harvey's work, see Anthony Grafton and Lisa Jardine, From Humanism to the Humanities. Education and the Liberal Arts in Fifteenth- and Sixteenth-Century Europe (London: Duckworth, 1986), 184-196. Harvey explicitly acknowledges the authority of Agricola and other scholars in his own published work: "Rodolph Agricola, Philip Melanchton, Ludouike Viues, Peter Ramus, and diuers excellent schollers, haue earnestly complained of Artes corrupted, and notably reformed many absurdities" (Gabriel Harvey. Foure Letters, 56)

${ }^{7}$ Harvey, Foure letters, and certaine sonnets especially touching Robert Greene, and other parties, by him abused: but incidently of divers excellent persons, and some matters of note. To all courteous mindes, that will voutchsafe the reading (London: John Wolfe \& Robert Robinson, 1592, USTC 512126), H1v.
} 
associated with 'Civilitie or Rhetorique'. Here Nashe's aggressive attitude amounts to the rhetorical dismembering of Harvey's arguments and sentences, the overall butchering of his 'whole meaning'. To this effect, Nashe used the panoply of outlandish stylistic devices that were common currency in the literary and theatrical markets of late sixteenth-century London:

"His gayest floorishes, are but Gascoignes weedes, or Tarletons trickes, or Greenes crankes, or Marlowes brauados: his iestes, but the dregges of common scurrilitie, or the shreds of the theater, or the of-scouring of new Pamflets: his freshest nippitatie, but the froth of stale inventions, longsince loathsome to quick tastes: his shrouing ware, but Lenten stuff, like the old pickle herring: his lustiest verdure, but ranke ordure, not to be named in Ciuilitie, or Rhetorique: his only Art, \& the vengeable drift of his whole cunning, to mangle my sentences, hack my arguments, chopp and change my phrases, wrinch my wordes, and hale euery sillable most extremely, euen to the disioynting, and maiming of my whole meaning." 8

In contrast, Harvey proclaimed the need to temper one's style for the sake of civic harmony and peace, in what amounts to an attitudinal and rhetorical version of adiaphora. Whatever 'distempered phrase' may have unwillingly escaped the author's attention must be met by his reader's 'good acceptation with indifferency' (my italics):

It was my intention... so to temper my stile in every part: that I might neither seme blinded with affection, nor enraged with passion: nor partial to frend, nor prejudiciall to enemy: nor injurious to the worst, nor offensive to any... Which if I have altogether attained, without the least oversight of distempered phrase, I am the gladder: if failed in some few incident termes, (what Tounge, or Pen may not slipp in heat of discourse?) I hope, a little will not greatly breake the square, either of my good meaning with humanity, or of your good acceptation with indifferency. ${ }^{9}$

The urban circles of Harvey's London were, like the Madrid of Antonio López de Vega's Paradoxas racionales (1641), the milieus where "la comunicación de los hombres entendidos", i.e. the communication among men of understanding, was established through the exchange of tempered texts that were expected to be produced and met with indifferency. A generation after Harvey, López de Vega would describe these men of understanding as "los amantes de la filosofía (o del mediano, o sea del ínfimo orden civil), la nobleza del saber y la del obrar como racionales", i.e. "the lovers of philosophy (or of the middling, that is, of the inferior civil order), the aristocracy of knowing and acting as rational

\footnotetext{
${ }^{8}$ Gabriel Harvey, Pierces supererogation or a new prayse of the old asse. A preparative to certaine larger discourses, intituled Nashes s. fame (London: John Wolfe, 1593, USTC: 512372), $\mathrm{H} 4 \mathrm{v}-\mathrm{I} 1 \mathrm{r}$

${ }^{9}$ Harvey, Foure Letters, A2v. This quotation is taken from the preface, titled "To all courteous minds, that will voutchsafe the readinge"
} 
individuals". ${ }^{10}$ And this middling civil order expresses itself through an equally tempered register, presided by 'moderación' and 'prudencia' vs 'la pompa vana'. ${ }^{11}$ López de Vega also confirms that there was an international dimension to these originally domestic developments.

Paradoxas racionales is a dialogue between a courtier and a philosopher. In its first part these two protagonists visit a former courtier who, prey to worldly disenchantment, has given up his aulic ambitions and retired to a villa in the outskirts of the city. But in contrast with the traditional dichotomy between court and country, he has opted for a middle course between the stress of public life and the rural lifestyle of the country mouse. He wants the peace and quiet of nature without renouncing to the "comunicación de los hombres entendidos" that can only be enjoyed in a city that brings together individuals not just from from all over Spain, but also from foreign provinces and nations:

But, how can, even the most disenchanted and circumspect of wits, fail to enjoy the communication among men of understanding, who flock into Madrid in large numbers, not just from all over Spain, but from all foreign provinces and nations, many of them with the aim of settling here for $\operatorname{good} ?^{12}$

In contrast with Harvey's focus upon the stylistic and moral tenors of public debate and reader reception, Antonio López de Vega exemplifies the mercantilist pragmatism that drove a similar search for a universal adiaphoric reader. In 1652 he printed in a single volume a new edition of his political treatise El perfeto señor, sueño politico (first issued in 1626) alongside other unpublished material. ${ }^{13}$ In his prologue López de Vega provides an account of the strategies that authors had to adopt in their search for larger audiences. He declares he had been moved to publish a second edition of El perfeto señor because the first one issued very few copies. This scarcity had increased the demand for the book, and made it truly valuable. From this particular case López de Vega reaches the general principle that, by contrast with the rule of Nature, in which precious materials are rare, within human societies scarcity, by and of itself and for no other reason, turns things into precious commodities:

\footnotetext{
10 Antonio López de Vega, Paradoxas racionales, escritas en forma de diálogos del género narrativo la primera, del activo las demás, entre un cortesano i un filósofo, [1641] ed. E. Buceta (Madrid: Junta para Ampliación de Estudios \& Centro de Estudios Históricos, 1935), 46. Unless otherwise indicated all English translations are mine.

${ }^{11}$ López de Vega, Paradoxas racionales, in Buceta ed., 1935, 108.

12 "Pero la comunicación de los hombres entendidos, que no sólo de toda Hespaña [sic], más bien de todas las provincias y naciones extranjeras, acuden en tanto número a Madrid, i muchos d'ellos a vivir de assiento, ¿cómo puede dexar de apetecerla el más desengañado i más circunspecto sabio?" (Paradoxas racionales, ed. Buceta, 1935, 16).

13 El perfecto señor: sueño politico; con otros varios discursos, y ultimas poesias (Madrid: Imprenta Real, 1652)
} 
For particular reasons very few were printed in the first edition; and this was enough to increase the wish for it, because whereas it is more common in Nature for Precious things to be rare, what is just Rare, for no other reason and in no rare occasions, also becomes Precious. ${ }^{14}$

López de Vega adds that his work seeks to please both "a la edad Provecta" (old age) as well as the "Eruditos moços" (the enlightened youth), by combining in the same volume moral and political treatises with a collection of poems on a variety of topics. He does so because, at the end of the day, all authors seek common approval: "common Applause constitutes the achievement and convenience of those who write". ${ }^{15} \mathrm{He}$ concludes that the combination of light with heavy matter within the same volume is a stratagem to make his volume more vario and general and, quite literally, more ponderous: "the volume in the end, grows more varied, becomes more general, and more corpulent too". ${ }^{16} \mathrm{He}$ refers to this strategy as reasons of state for the use of any author who does not want to vanish from the public arena and the "common approval": "stratagems, all of them, and Reasons of State, for any author who does not wish to vanish by underestimating common approval". ${ }^{17}$

This combination of disenchanted pragmatism and the language of Machiavellian Tacitism in the public sphere, with the private neostoic morality of the philosophical middle ground provided a political vocabulary which could also be used for the intellectual legitimation of self-interested, commercial strategies in the production and distribution of volumes like this one. The political historian Richard Tuck has emphasised the mercantilist language used by reason of state writers as one of the main differences between the public morality of sixteenth century Ciceronian humanism, and the neostoicism of the the early seventeenthcentury. ${ }^{18}$ This pragmatic spirit, combined with a tempered and colloquial prose style evinces echoes of Cicero-some of which might have reached López de Vega via Montaigne's famous essay on "De 1 'utile et de 1 'honnête". ${ }^{19}$ In his

\footnotetext{
14 "Por fin particular se imprimieron la primera vez muy pocos; i basto esto para hazerse deseado, que si bien es mas común en la Naturaleza, el ser lo Precioso raro sabe también no raras veces, sin que concurra otra razón, hazerse lo Raro Precioso.” (López de Vega, 1652, [5])

15 "En el común Aplauso consiste el logro, i conveniencia del que escribe", ibid., [6].

16 "El Volumen, al fin se haze con esto mas vario, se haze mas general, i tambien mas corpulento", ibid., [7].

17 "Estratagemas todas, i Razones de Estado de cualquier Escritor, que no quiera desvanecerse, en hazer punto del Menosprecio del comun Agrado" (ibid. [7])

${ }^{18}$ Richard Tuck. Philosophy and Government, 1572-1651 (Cambridge, UK: Cambridge University Press, 1993), xii-xiii. On the pragmatism of López de Vega and its intellectual foundations, see César A. Núñez, "Un solitario en la corte. Las Paradoxas racionales de Antonio López de Vega", Nueva Revista de Filología Hispánica, (2007:55), 77-119, 97-8, et passim.

19 "On the useful and the honourable" in M.A. Screech's recent translation (M.A. Screech, trans. Michel de Montaigne, The Complete Essays, Harmondsworth: Penguin, 1993; the essay is in Book III, 891-906). In 1613 John Florio traslated it, more significantly, as "On Profit and Honesty": a rendering that does justice to the complex dimensions of the original (including its mercantilist overtones) and its English reception within the milieu of early seventeenth-century London (John
} 
"Paradoja sexta", López de Vega proclaims that "I do not intend in this doctrine to establish what is more honest, but to find what in the matter we are disputing about is usually more useful". ${ }^{20}$ The matter he is discussing in this particular section is literary controversy, and the subtitle of this paradoja reveals its selfinterested pragmatism: "in literary controversies, modesty is more unhelpful than profitable, and those who cannot come forth with a fearsome tenor will not gain any estimation in their substance". ${ }^{21}$

The preface to López de Vega's Heráclito y Demócrito de nuestro siglo... Diálogos morales sobre tres materias, La Nobleza, La Riqueza y Las Letras (Madrid: 1641) demonstrates how the pragmatic search for the ideal reader also facilitated the creation of a new standard for a learned but tempered style that does not indulge in extremes. In a prologue that he addresses to those "few sane and disenchanted men" ("A los pocos cuerdos y desengañados varones", 1641, p. [14]), he proclaims his disdain for the ignorant crowd, and within this category of vulgus he includes arrogant aristocrats, the ungenerous and vainglorious plutocrats, as well as impertinent pedants:

I write only for you. Odi profanum Vulgus, \& arceo, whether those who, because they enjoyed an illustrious birth and without any personal effort, esteemed themselves above others; whether those who, because they are wealthy, believe they are something and not tending to the succour of others, desire to be vainly worshipped, and this vanity they want at a low cost; whether those who swell and vanish because they are studious and witty in impertinent matters. More or less lucid, all of these are for me part of the Vulgar, and I will not accept any Vulgar imparting Judgment upon my Writings. ${ }^{22}$

He justifies the common and colloquial register that he is about to use in this work, mixing the high with the low, because classical doctrine dictates that the familiar style most fits a dialogue. The diversity of the speakers and the variety of topics justify the occasional plebeian expressions and turns of phrase. They also

Florio, trans. Essays written in French by Michael Lord of Montaigne, London: Printed by Melch. Bradvvood for Edvvard Blount and William Barret, 1613, STC (2nd ed.) 18042, 443-451).

20 "no es mi intento determinar en esta doctrina lo que es más honesto, sino descubrir lo que en la materia que disputamos suele ser más útil" (López de Vega, Buceta, ed. 1935, 128; my italics); in p. 132 López de Vega insists again that he is more interested in what is useful, rather than what is honest.

21 "En las contiendas literarias, más desayuda que aprovecha la modestia, i el que no se hiziere temer con el modo no se hará estimar en la sustancia" (ibid.)

22 "Para vosotros sólo escribo. Odi profanum Vulgus, \& arceo, ya sea el que por haber nacido Ilustre, sin poner nada de su parte, piensa ser más que los otros; ya el que por verse rico, imagina que es algo; y no atendiendo al Socorro ajeno, quiere vanamente ser venerado, y que la vanidad le cueste poco; ya el que se hincha y desvanece por Estudioso, y Docto en lo impertinente. Más o menos lúcido, todo esto para mi es Vulgo; y a ningún Vulgar admito al Juicio de mis Escritos." (1641, p. [14]) 
account for the combination of serious and comic matter, all for the sake of the verisimilar recreation of what goes on in an authentic conversation:

Regarding style, you know that out of all the diversity of ideas and manners of speech that the Greeks excogitated and were followed by the Romans, the familiar style most befits a dialogue; although, depending on the persons who participate in it, it can admit Courtly Elegance, and also some terms from science; this is after all, an imitation of the manner in which speakers communicate with each other. Thus, you will not be offended that, amongst my Courtiers and Philosophers, language may circulate common and unaffected, and that, depending on the matter, it may wax ornate, or somewhat elevated; it may even debate and speak, on occasion, in Scholastic terms; for there is no sin in unevenness here; nor is there in the use of any plebeian and jesting word or phrase, introduced amidst the most grave, because, insofar as it befits the circumstance and the particular occasion, it results in the proper imitation of what goes on in conversations amongst jocular wits. ${ }^{23}$

Thomas Nashe and Gabriel Harvey were also engaged in a particular case of "comunicación de los hombres entendidos"-albeit not one held in the civilized terms that Harvey promoted, as we have seen. Nashe is another example of a hack situated between the networks of patronage and the pursuit of a new status as an independent author-in other words, as increasingly dependent on the material conditions of the market. He also appears concerned with the mercantilization of literary discourse that the publishing business has brought about. In his preface to Greene's Menaphon he declares his intention to "persecute those idiots and their heirs unto the third generation, that have made Art bankerout of her ornaments, and sent Poetry a begging up and downe the Countrey". ${ }^{24}$ Nashe's earliest work, The Anatomie of Absurditie (1589) was presented in its dedicatory preface as a satire on the defacers of Art. ${ }^{25}$ In the same introduction Nashe gives the reader an account of a conversation with other men "of most

23 "En cuanto al estilo, ya sabeis que de las varias ideas, y caracteres del decir, que excogitaron los griegos y siguieron los romanos, es el familiar el que pertenece al diálogo; si bien, según las personas introducidas, puede admitir toda la Elegancia Cortesana, y algunos términos también de las ciencias; imitación, al fin, de la forma con que suelen comunicarse los que se introducen. Así no os ofenderá que entre mis Cortesanos Filósofos corra tal vez común y desenfadado el lenguaje, y tal (conforme a la materia) se realce, y encrespe un poco; se arguya, y hable en alguna occasion, a lo Escolástico; que no es aquí la desigualdad pecado; como ni también alguna voz o frasis plebeya, i de chanza, entreverada entre las graves, porque guardándose la circunstancia de la ocasión, se viene así a imitar con propiedad lo que pasa en conversaciones de doctos joviales." (1641, pp. [17-18])

24 Thomas Nashe, "To the Gentlemen Students of both Uniuersities", in Robert Greene, Menaphon, London: Printed by T[homas] O[rwin] for Sampson Clarke, and are to be sold behinde the Royall Exchange, 1589, USTC: 511254, A3r

${ }^{25}$ The anatomie of absurditie: contayning a breefe confutation of the slender imputed prayses to feminine perfection, with a short description of the seuerall practises of youth, and sundry follies of our licentious times. At London : Printed by I. Charlewood for Thomas Hacket, 1589, USTC: 511295. 
excellent parts" which takes as its starting point Castiglione's Courtier. Each of these men of understanding defends a particular virtue as the true badge of a good courtier. One of them declares this to be facetudinis, which Nashe translates as discoursing - and which can be identified with the moderation and reasonable affability defended by Harvey. ${ }^{26}$ The fourth interlocutor in this conversation declares that the true courtier must simply show scholarship and courage. Conversation woven with reasonable discoursing constitutes the link that facilitates the creation of this community of gentlemen-scholars debating on the nature of true courtesy. Participation in civilized conversation in turn legitimizes each of them as members of a new type of nobility, the meritocracy of gentle wit or the republic of letters:

So it was, that not long since lighting in company with manie extraordinarie Gentlemen, of most excellent parts, it was my chance (amongst other talke which was generally trauersed amongst vs) to mooue diuers Questions, as touching the seueral qualities required in Castalions Courtier: one came in with that of Ouid, Semper amabilis esto, another stood more stricktly on the necessitie of that affability, which our Latinists entitle facetious, \& we more familiarlie describe by the name of discoursing: the third came in with his carpet deuises, and tolde wyat it was to tickle a Citterne, or haue a sweete stroke of the Lute, to daunce more delicatlie, and reuell it brauelie. The fourth as an enemie to their faction, confuted all these as effeminate follies, and would needs maintaine, that the onely adiuncts of a Courtier, were schollership and courage, returning picked curiositie to paultry Scriueners and such like, affability to Aristipus and his crue, Citterning and Luting, to the birthright of euerie fixe pennie flaue, and to conclude, dauncing \& reuelling, to euerie Taylors holie day humour., 27

A similar idea finds a new expression some decades later in López de Vega's "veneration for the true and natural aristocracy of the intellectual parts and rational customs". ${ }^{28}$

\footnotetext{
${ }^{26}$ See for instance Cicero, De oratore, I.viii.32-34; Cicero, De officiis, I.vii.23. On the notion of language as currency, see also Horace's The Art of Poetry, 58-62, 70-72; Quintilian, Institutio Oratoria, I.vi.3. There are frequent echoes of this doctrine in early modernity: Giovanni Pontano's De sermone (De bello neapolitano et de sermone, Napoli, ex officina Sigismondo Mayr, 1509, USTC: 850303) constitutes one of the most eloquent examples: see for instance book I.iii.1-2, also book I.xiii, 1; book I.vii, 1(Giovani Giovano Pontano, De Sermone. De la conversation. [1509] Texte établi et traduit par Florence Bistagne. Paris: Honoré Champion, 2008). See also Juan Luis Vives's In pseudodialecticos [1519], ed. Charles Fantazzi, (Leiden: E.J. Brill, 1979), 36, 39.

${ }^{27}$ Nashe, 1589, dedicatory preface "To the right worshipfull Charles Blunt Knight", p. [3]

28 “... veneración para la verdadera i natural nobleza de la parte intelectual i costumbres racionales”, López de Vega, Paradojas racionales, Buceta ed. 1935, 42.
} 


\section{III}

\section{Translation, Common Sense and the Currency of Language}

The different pressures exerted by literary, intellectual, religious and political controversy in combination with the structural shifts in the production and distribution of literary discourse resulted thus in the emergence of the discerning reader as an enlightened consumer who engaged in conversation with his peers through the currency of a common register. This civilized exchange legitimised the pursuit of self-interest within a mercantile milieu, and enfranchised the eloquent speaker as a citizen in the republic of letters. The rules for this kind of intercommunicative self-fashioning arose from the examples and doctrines contained in humanist dialogues and, more explicitly, in the manuals on the art of conversation that proliferated in the sixteenth and early seventeenth centuries. Handbooks for language learning, multilingual anthologies, phrasebooks, collections of proverbs and aphorisms in several languages, but above all, translations, were the vehicles that facilitated the circulation of communicative currency and constituted the infrastructure for the establishment of a truly European conversation among men of understanding. ${ }^{29}$

The use of similar vocabularies for trade, translation and the establishment of common linguistic norms had already become an incipient trend well before the turn of the sixteenth century. The concerns about reader reception had also made a debut, in particular as regarded the social and individual consequences of the emotional potential within the texts that were starting to circulate in ever larger amounts. In La Celestina (first published in 1499) Fernando de Rojas had already created with his character Calisto the model of a distempered reader of popular romance fiction who prefigured Alonso Quijano as the obsessive consumer of chivalric fiction, another variety of popular print commodity. Portrayed as a tragicomic negative example for Rojas's readership, Calisto comes through as an immature brat who had fashioned his emotional life after the rhetorical models provided by the sort of Ovidian and Petrarchist texts that were so popular at the time. In the face of Calisto's rants, his servant Sempronio commonsensically advises him to abandon those poetic hyperboles, and turn to the language which is common to all, and which all can understand ${ }^{30}$ Fernando de Rojas was a student

\footnotetext{
29 Recent scholarship on this subject includes Joyce Boro, "Multilingualism, Romance, and Language Pedagogy; or Why Were So Many Sentimental Romances Printed as Polyglot Texts?" in Tudor Translation, ed. by F. Schurink (London: Palgrave, 2011), 18-38 and Rocío G. Sumillera, "Language Manuals and the Book Trade in England", in Translation and the Book Trade in Early Modern Europe, ed. by José María Pérez Fernández and Edward Wilson-Lee, (Cambridge: Cambridge University Press, 2014), 61-80.

30 "Good sir, leave off these circumlocutions; leave off these poetical fictions: for that speech is not comely which is not common unto all, which all men partake not of as well as yourself, of which few do but understand." (Fernando de Rojas, The Spanish Bawd [1631] (La Celestina,
} 
in Salamanca when the Spanish grammarian and rhetorician Elio Antonio de Nebrija was engaged in the grammatical and stylistic homogenization of Castilian upon the principles of authoritative legitimacy and common usage provided by the epistemological and linguistic model of the Italian scholar Lorenzo Valla. Valla, in turn, had pioneered a refashioning of scholastic dialectic and philosophy through classical rhetoric, with a particular emphasis on the importance of consuetudo and usus loquendi as principles for proper language use and, most importantly, as epistemological tools for the articulation and communication of knowledge. ${ }^{31}$

This epistemological and linguistic background runs parallel to the development of the new trends within the book markets that we have been tracing over the course of the sixteenth and the early seventeenth centuries. In combination with the joint pressures of market mechanisms and censorship, there were three other different pulls building up the main tensions that would eventually lead to the apperance of this discerning reader. ${ }^{32}$ First there was the ignorant multitude, the large variety of consumers who could afford easy access to printed material in the vernacular. But beyond print, these audiences had also gained access to literary discourse through the public stage in even larger amounts. In the second place, there were the more prestigious circles of learned authors and readers, either those associated with aristocratic values - among them the courtly elite audiences for certain types of lyric and epic poetry-or those attached to academic and ecclesiastical cadres, such as the international elite of Neo-Latin readers. The third one resulted, as we have seen, from the need to carve out a new public space, at the same time distinct from ancient aristocratic values and their heroic ideals, but also surgically excised from the contaminating contact with the affect-dominated vulgo, the ignorant multitude and their base instincts. These pulls eventually led to the emergence of the concepts of understanding and taste, discreción and ingenio, as the inherent potentials of a new discerning reader whose tempered style engaged in a conversation with other men to weave a language common to all.

The paratexts in Mateo Alemán's Guzmán de Alfarache ( $1^{\text {st }}$ part, Madrid, $1599,2^{\text {nd }}$ part Lisbon, 1604), translated into English by James Mabbe as The Rogue, or the life of Guzman de Alfarache (London: Edward Blount, 1623) exemplify this threefold division of tensions. This picaresque novel features three different prologues. The first is a dedication to an aristocratic patron, Don Francisco de Rojas, the second is addressed "al vulgo", and the third "al discreto

[1499]), trans. James Mabbe, ed. José María Pérez Fernández, London: MHRA, 2013, 8.345-48, 228.

${ }^{31}$ For further details, see Lodi Nauta, In Defense of Common Sense. Lorenzo Valla's Humanist Critique of Scholastic Philosophy (Cambridge, MA and London: Harvard University Press, 2009), 274-291.

32 On the discerning reader see Julian Weiss, "Between the Censor and the Critic: Reading the Vernacular Classic in Early Modern Spain”, in María José Vega, Julian Weiss, \& Cesc Esteve, eds. Reading and Censorship in Early Modern Europe (Bellaterra: Universitat Autònoma de Barcelona, 2010), 93-112, 95-6. 
lector". The succession of these three different prologues, skillfully linked to each other by allusion and rhetorical disposition, constitutes Alemán's enaction of the dialectics of the period: first, an appeal to the aristocracy in order to obtain legitimacy and protection from the onslaughts of the vulgar; this ignorant crowd in turn gets its own rebuke in the second prologue; the final resolution rises through Alemán's appeal "al discreto lector". In seeking the protection of an aristocrat, Mateo Alemán displays his anxieties before the mass audiences of vulgar readers: “. . . it was needful for me, to helpe my selfe, and make vse of your Lordships protection...", ${ }^{33}$ he declares, from those of "evill intention... and secret ill meaning", that is, the commoners he describes as "those that are of obscure Bloud, humble Birth, and base mindes". ${ }^{34}$ Alemán acknowledges that the publication of his book has exposed him to the opinion and censure of the vulgar: "the Barbarisme, and dis-equall number of those ignorant Dolts, to whose censure I submitted my selfe". ${ }^{35}$

Against this background, Lope de Vega's famous claim in his Arte nuevo de hacer comedias (Madrid, 1609) that his poetics were dictated by the tastes and demands of the vulgo, and that he devised his comedies to please the "ignorant multitude", reveals the true measure of its provocative intent. "I write", Lope proclaimed, "following the rules of the art invented by those who sought the applause of the vulgar: since the vulgar pays for them [i.e. my comedies], it is fair to address them in vulgar terms to please them". 36 The most recent editor of Lope's Arte, García Santo-Tomás, has emphasized the non-prescriptive nature of Lope's Arte nuevo, but rather the fact that it simply described the situation of the stage in Madrid. García Santo-Tomás adds that beyond the academic audience for which it was initially composed - it was first delivered as an oration before a literary academy in Madrid - the Arte Nuevo addresses his ideal, implicit reader. ${ }^{37}$

Alemán's appeal to the "discreto lector" in the third prologue proclaims that his aim in writing this work has been to serve the common good: "it was my sole purpose, to guide the prow for the publicke good, if I might be worthy to

\footnotetext{
${ }^{33}$ Mabbe, trans., The Rogue, 1623, [4v]; “... fue necesario valerme de la protección de Vuestra Señoría, en quien con tanto resplandor se manifiestan las tres partes—virtud, sangre y poder-de que se compone la verdadera nobleza" (Mateo Alemán, Guzmán de Alfarache, ed. de José María Micó, Madrid: Cátedra, 1987, 2 vols., I, 107)

${ }^{34}$ Mabbe, trans., The Rogue, 1623, [4r]; "De las cosas que suelen causar más temor a los hombres, no sé cuál sea mayor o pueda compararse con una mala intención; y con mayores versa cuanto más estuviere arraigada en los de oscura sangre, nacimiento humilde y bajos pensamientos" (ibid., 106, my italics).

35 Mabbe, trans., The Rogue, 1623, [6r]; "Tal he salido del proemio pasado, imaginando en el barbarismo y número desigual de los ignorantes, a cuya censura me obligué, como el que sale a voluntario destierro y no es en su mano la vuelta" (ibid., 110)

36 “... y escribo por el arte que inventaron / los que el vulgar aplauso pretendieron / porque, como las paga el vulgo, es justo / hablarle en necio para darle gusto" (Lope de Vega, Arte nuevo de hacer comedias en este tiempo, Madrid, 1609, lines 45-48)

37 Enrique García Santo-Tomás, ed. \& introd. Lope de Vega, Arte nuevo de hacer comedias, (Madrid: Cátedra, 2006), 44-45; on Cervantes and his quest for popularity and the discerning reader, see García, ed., 2006, 67.
} 
obtaine so great a blessing" ${ }^{38} \mathrm{He}$ gives full leave to the discreet reader to moralize at his pleasure, with a wide margin of liberty to do so: "In this Discourse, thou maist moralize things, as they shall be offered unto thee, Thou hast a large margent left thee to doe it". ${ }^{39}$ The discerning reader appears in possession of an understanding capable of exercising the freedom to interpret a potentially ambiguous or even pernicious text in a responsible manner, without incurring in the follies and perversions of misreaders like Calisto or Alonso Quijano. The interpretation of the text is left to the liberal imagination of each among these discreet and autonomous readers.

A similar attitude can be detected in prologues and dedications of English plays during the late sixteenth and the early years of the seventeenth centuries. Michael Neill has provided very revealing statistics about the plays produced and published over the period 1576-1642, many of which yield a virtual list of discerning cognoscenti made up of all the dedicatees of their prologues. ${ }^{40}$ They constitute the elite that Glapthorne, in the prologue to his Lady's Privilege, calls "Wits most accomplished Senate". ${ }^{41}$ It is significant that this trope appears in the context of Caroline audiences and their taste for tragicomedies, in particular when we take into account the parallelism that Guarini had established between tragicomedies and republics, both of which mixed the higher with the lower classes. This made them more verisimilar and representative, in poetic as well as in political terms. Guarini declares that tragicomedies are "mirrors of human relations":

Has it not been said before that poetry employs actions and persons? We may give, then, an example of them. Do not Marcus Tullius and Horace say comedy is the mirror of human relations? We may give an example from human relations. Does not Aristotle say that tragedy is made up of persons of high rank and comedy of men of the people? Let us give an example of men of rank and men of the people. The republic is such a thing... Is not tragedy an imitation of the great and comedy an imitation of the humble? Are not the humble opposite to the great? Why cannot poetry make the mixture if politics can do it? ${ }^{42}$

\footnotetext{
${ }^{38}$ Mabbe, trans., The Rogue, 1623, [6r]; "a solo el bien común puse la proa, si de tal bien fuese digno que a ello sirviese" (ibid., 111).

39 Mabbe, trans., The Rogue, 1623, [6v]; "En el discurso podrás moralizar según se te ofreciere: larga margen te queda" (ibid., 112). My italics.

40 Michael Neill, Michael Neill, "Wits most accomplished Senate': The Audience of Caroline Private Theaters", Studies in English Literature (1978: 78): 341-60. The plays that he samples include Webster's dedication to The Devil's Law Case (1623) and The Duchess of Malfi (1633), or Heywood's dedication to Marlowe's Jew of Malta, Middleton's preface to The Roaring Girl (1611).

41 "The audience's corporate sense of itself as (in a metaphor the dramatists frequently employ) 'a court of taste', 'Wits most accomplished Senate', as Glapthorne called it in his Lady's Privilege prologue (1637-1640)" (Neill, 1978, 344).

${ }^{42}$ Guarini, The Compendium of Tragicomic Poetry (1601), in Allan H. Gilbert, Literary Criticism. Plato to Dryden (New York: American Book Company, 1940), 510-511.
} 
Authors in Spain and in England offered their texts as merchants offered their commodities. In the same page in which he acknowledges the freedom that the discerning reader enjoys when it comes to interpreting his text, James Mabbe freely translates Alemán's original, which in its English version admits that "this is merchantable ware, well-conditioned; and for such I recommend it unto thee". ${ }^{43}$ And in England, Marston's Induction to his Malcontent declares that "any man that hath wit may censure if he sit in the twelve-penny room". ${ }^{44}$ In other words, a discerning wit in combination with purchasing potential enfranchises audiences to become magistrates at the court of taste. Like Lope de Vega in Madrid, London playwrights courted mixed audiences, which included the mosqueteros (the Spanish equivalent of the groundlings among London audiences), the aristocracy, and those individuals of discreet understanding. The relevance of the stage, in London and Madrid, as one of the main factors involved in the commodification of literary discourse appears in the tropes that some authors used when they expressed their anxieties about having to compete not just among the understanding courts of taste, but also within the more populous and unpredictable marketplace of print. Harvey, in the letter to Spenser mentioned above, complains that, by being printed and thus having his name exposed in the public arena he has become a sort of comic actor:

And canst thou tell me nowe, or doist thou at the last begin to imagin with thy selfe what a wonderfull and exceeding displeasure thou and thy printer have wrought me, and howe peremptorily ye have preiudishd my good name for ever in thrusting me thus on the stage to make tryall of my extemporall faculty, and to play Wylsons or Tarletons parte? ${ }^{45}$

Opinions about the ignorant crowd, and the vulgo, wavered in this period between those who despised and feared it, like Alemán, and those others who considered vulgar wisdom a sort of natural wit, spontaneous, uncontaminated by prejudice and therefore authentic. In seeking the protection of the aristocratic patron, or the approval of the discerning reader, authors were casting their lot with these social, or intellectual, elites, i.e. submitting to their authority as they sought their legitimacy. They did so in fear of the new type of authority that had arisen out of the new material conditions for the production of literary discourse: the vulgo, the looming ignorant crowd that expressed its views through the abstract notion of common opinion. In his play Fair Maid of the Inn (1626) Fletcher declares that "plays have their fates".

not as in their true sence

They're understood, but as the influence

Of idle custom, madly works upon

\footnotetext{
${ }^{43}$ Mabbe, trans., The Rogue, 1623, [6v].

${ }^{44}$ Quoted by Neill, 1978, note 23, 345.

45 "To his very unfrendly frende that procurid the edition of his so slender and extemporall devises", in Grosart, ed. 1884, 125.
} 
The dross of many tongu'd opinion. ${ }^{46}$

Two years later (1628), the Spanish playwright Juan Ruiz de Alarcón published his Comedias in Madrid. His volume included the following address to the vulgo:

I speak to you, fierce beast... there you have those comedies, deal with them as is your wont: not as it is fair, but as is your taste; they scorn you, and do not fear you, because they already underwent the dangers of your hissing, and now they can only suffer your ignorance. If they displease you, I will be pleased to know they are good, and if they are not, I will feel avenged by the money they must cost you. ${ }^{47}$

The joint action of the vulgo - the mass of consumers of literary discourse - and opinion - the powerful leverage of commonly held views wielded by these audiences - conspired with the linguistic norms fixed by common usage to destabilize preestablished structures of signification and linguistic decorum. All these factors worked within a framework in which common sense was emerging as a mode of knowledge, a novel variety of epistemology within which the particular subject and the social universe interacted in a new fashion. The power of discreción is fundamental here as the tempering agent. Discreción is an inherent capacity that is not related to social extraction and displays itself in language. Cervantes proclaims in the second part of Don Quijote that:

El lenguaje puro, el propio, el elegante y claro, está en los discretos cortesanos, aunque hayan nacido en Majalahonda; dije discretos porque hay muchos que no lo son, y la discreción es la gramática del buen lenguaje, que se acompaña con el uso. ${ }^{48}$

In 1620 Thomas Shelton rendered this passage thus:

The language is pure, proper, and elegant, (indeed) only in your discreet Courtiers, let them be borne where they will: discreet I say, because many are otherwise, and discretion is the Grammar of good language, which is accompanied with practice. ${ }^{49}$

\footnotetext{
${ }^{46}$ Quoted by Neill $(1978,348)$

47 “Contigo hablo, bestia fiera... Allá van essas Comedias, trátalas somo sueles, no como es justo, sino como es gusto, que ellas te miran con desprecio, y sin temor, como las que pasaron ya el peligro de tus silvos, y ahora pueden solo pasar el de tus rincones. Si te desagradaren, me holgaré de saber que son buenas, y si no, me vengará de saber que no lo son, el dinero que te han de costar" (Parte primera de las comedias de Juan Ruiz de Alarcón y Mendoza, Madrid, por Iuan Gonçalez, a costa de Alonso Perez, 1628, fol. Ivv).

${ }^{48}$ Miguel de Cervantes, Don Quijote de la Mancha (Alberto Blecua, ed. Madrid: Austral, 2004), II.xix, ("Donde se cuenta la aventura del pastor enamorado, con otros en verdad graciosos sucesos"), 855 .

${ }^{49}$ Thomas Shelton, trans. The Second Part of the History of the Valorous and Witty Knight-Errant, Don Quixote de la Mança, (London: Edward Blount, 1620), 122-123
} 
The significant evolution of the concept and the general universe of discourse that sustains it is then splendidly inscribed in Tobias Smollett's eighteenth-century translation-still common currency among English readers today. Here Cervantes' 'discretos cortesanos' and Shelton's 'discreet Courtiers' have been naturalised as quintessentially Enlightened 'polite people of sense':

Purity, propriety, elegance and perspicuity [in language] are to be found among polite people of sense, tho' they be natives of Majalahonda: I say people of sense, because so great a number of people are not so, and sense is the foundation of good language, assisted by custom and use. ${ }^{50}$

In his Viaje del Parnaso (1614) Cervantes acknowledges that the vulgo of Madrid were discreet enough to discern what was aesthetically proper and what not. In a frantic mock-epic episode which describes an allegorical battle of contemporary books and authors, the narrator of the poem expresses his amazement at the fact that bad plays manage to pass themselves off as divine, and aspire to be known and traded in the public sphere ("en el corro") at the expense of some other truly excellent plays; he concludes that the pretence of the former was to no avail in this market ("no ganaron mucho en esta feria") since the vulgo of Madrid is discreet ("Porque es discreto el vulgo de la Corte"). ${ }^{51}$ They may have disagreed on many other matters, but Lope de Vega and Miguel de Cervantes agreed in their common estimation of the literary opinion of the vulgo.

Dámaso de Frías, a contemporary and personal friend of Cervantes, was also a defender of common usage as the norm for proper and decorous language:

Since, as I have just said, it is usage, and only usage, what establishes and abolishes the propriety and rules of languages, I am of the opinion that all those who want to speak or write must make use of words and terms that, even though they may be new or farfetched, are already in use among men of discretion and authority. ${ }^{52}$

De Frías was also the author of an essay titled Diálogo de la discreción (composed ca. 1579). This treatise belongs in the tradition of the arts of

\footnotetext{
${ }^{50}$ Miguel de Cervantes, Don Quixote. Trans. Tobias Smollett (New York: The Modern Library, 2004), Book II, in vol. II, chapter II, ("In which is recounted the adventure of the enamoured shepherd, with other truly diverting incidents"), 710.

${ }^{51}$ Miguel de Cervantes Saavedra, Viage del Parnaso (Madrid: Viuda de Alonso Martín, 1614), book VII.313-321, 59-60.

52 "Siendo, pues, como digo, sólo el uso quien quita y pone en las lenguas propiedades y leyes de ellas, soy de parecer que con éste se tenga en cuenta y a éste sirvan cuanto bien quisieren hablar y escribir, y de aquellas palabras y términos se aprovechen, que, aunque nuevas o peregrinas, estén ya introducidas en el trato y uso de algunos discretos y autorizados hombres", Dámaso de Frías, Diálogo de la discreción (composed ca. 1579), printed for the first time in Diálogos de diferentes materias. Prol. F. Rodríguez Marín; ed. Justo García Soriano. Colección de Escritores Castellanos. Críticos. Tomo 161 (Madrid: Imp. de G. Hernández y Galo Sáez, 1929), 272-273; quoted in J.L. Pensado, Una crisis en la lengua del imperio. El Diálogo de las Lenguas de Damasio de Frías. (Salamanca: Ediciones de la Universidad de Salamanca, 1982), 48-50.
} 
conversation, and takes as its starting points Castiglione's Il Cortegiano and Giovanni Della Casa's Galateo (1558), coinciding also in time with other European handbooks on the art of conversation like Stephano Guazzo's La civil conversazione (1574). ${ }^{53}$ The art of conversation, in the opinion of de Frías, rests upon the pillars of moderation and decorum. Conversation must always adapt itself to the communicative context in which it takes place, following the discreción of each of the interlocutors. The adaptation of speech to communicative context through the application of the speakers' discreción results in "un gentil y acertado discurso de raçon", i.e. a gentle and proper discourse of reason. ${ }^{54}$ De Frías defines discreción as the eminently practical application of a natural gift in human nature, one of those powers in the human soul that resulted from God's creation of man in His own image and likeness. As with discreción, thus with poetic creativity, which has the potential to manifest itself in any individual, since, as Cervantes declares in his Persiles \& Segismunda "las almas todas son iguales", i.e. all souls are equal. According to Cervantes, discreción is a common, God-given kind of understanding:

It is possible for an artisan to be a poet, because poetry is not in the hands, but in the understanding... because all souls are equal, and of the same primaeval matter created and shaped by their Maker. ${ }^{55}$

\footnotetext{
${ }^{53}$ Della Casa's work was translated into English by Robert Peterson in 1576 (Galateo... Or.. A treatise of the ma[n]ners and behauiours, it behoueth a man to vse and eschewe, in his familiar conuersation. London: [By Henry Middleton] for Raufe Newbery, 1576). George Pettie and Bartholomew Yong translated Guazzo's The Civile Conversation-Pettie translated the first three books in 1581 and Yong the fourth one in 1586 (The ciuile conuersation of M. Stephen Guazzo, written first in Italian, diuided into foure bookes, the first three translated out of French by $G$. pettie. In the first is contained in generall, the fruits that may be reaped by conuersation ... In the second, the manner of conuersation... In the third is perticularlie set forth the orders to be obserued in conuersation within doores, betweene the husband and the wife... In the fourth is set downe the forme of ciuile conuersation, by an example of a banquet, made in Cassale, betweene sixe lords and foure ladies. And now translated out of Italian into English by Barth. Young, of the middle Temple, Gent. Imprinted at London : By Thomas East, 1586). Harvey owned an annotated copy of de Guazzo's original (S. Stefano Guazzo, La Civil Conversatione... Divisa in III. Libri. Venice, Gratioso Percacino, 1581) and also an edition of George Pettie's 1581 translation of the first three books (The Civile Conversation of M. Steeven Guazzo. London, Richard Watkins, 1581). See Virginia F. Stern, Gabriel Harvey. A Study of His Life, Marginalia, and Library (Oxford, UK: Oxford University Press, 1979), 161, 217-8.

54 "The task of the discreet is no other than, through a gentle and proper discourse of reason, to accommodate the things being dealt with, and dealing with them, according to the decorum of place, time, people, and motivation, as well as according to any other circumstance that may concur". The original runs thus: "Es pues offiçio del discreto no otro que con un gentil y acertado discurso de raçón saber acomodar las cosas de que tracta y tractar dellas conforme al decoro del lugar, del tiempo, de las personas, del porqué, y ansí de las demás circunstancias, si algunas ay otras" (42)" (Damasio de Frías, quoted in Jesús Gómez "La 'Conversación discreta' de Dámaso de Frías y los estudios sobre el arte de conversar”, Hispanic Review, vol. 75, 2007:2, 95-112, 104) This of course, echoes Jardine's definition of Harvey's linguistic ideal as the art of "reasonable discoursing"

55 "Posible cosa es que un oficial sea poeta, porque la poesía no está en las manos, sino en el entendimiento ... porque las almas todas son iguales y de una misma masa en sus principios criadas y formadas por su Hacedor." Cervantes, Los Trabajos de Persiles y Sigismunda, (Madrid:
} 
There is thus an inherent potential in all individuals that can turn a simple tailor into a poet, or a humble artisan into a discerning reader, and therefore become enfranchised to hold one of those discreet conversations described by Damaso de Frías. When these men of understanding, whose capacities go beyond the traditional values of the ancient aristocracy, engage in conversation they create the virtual circles of the neoelitist Court of Taste. The discreet reader thus shows the capacity to draw the right moral lessons and to appreciate the aesthetic quality of proper literary discourse. This subjective capacity turns into common sense when it gains its social dimension, when the men of understanding communicate with each other. This announces a new modality in the articulation of the rapport between particulars and universals, the subjective and the social, through the link of language and rhetoric. ${ }^{56}$ What conversation signifies within the context of the city, translation facilitates at the international level. Translation weaves a rich and complex conversation among men of understanding made possible by the currency of language and its exchange value, which is established with the aid of dictionaries and handbooks for language-learning. As mentioned above, these works frequently took the form of literary anthologies, collections of adagia, or conversation manuals. The highly controversial translation of Scripture had already unlocked the source of God's grace from the hands of those who would monopolize it, and the translation of all sorts of texts was now making secular knowledge available to the common of humanity for its mutual profit. The spread of knowledge through translation is compared to international trade, and those who criticize the task of translations and translators are like greedy merchants bent on monopolizing the market. The following is a spirited defence of translation by Thomas James that appears in the preface to his English rendering of Brucioli's Commentary upon the Canticle of Canticles (1598):

Translators haue their faults and abuses as well as other men, as when they translate the foolish \& vnprofitable, or wicked \& vngodly books, or els mistranslate \& misinterpret books, and then the abuse proceedeth either of malice or of ignorance: if of malice their reproofe is iust; if of ignorance, blame them not, vnles it be affected: for the best that is may misse in a strange language, when no man knoweth all in his owne tongue. And thus far reacheth their complaint against the abuse of translations, which may in no wise be excused. As for the harme that cometh by making learning too common, men of common judgment may by vulgar examples easily refute

Juan de la Cuesta, 1617) Book I, chap. XVIII, 43v. For more details on the debate between nature and nurture when it came to poetic gifts in the context of the Spanish Siglo de Oro, see Otis H. Green, "On the Attitude Toward the Vulgo in the Spanish Siglo de Oro", Studies in the Renaissance (1957:4), 190-200, 195-96. For a recent account of political discourse and moral philosophy in the literature of Miguel de Cervantes, see Antony Cascardi's Cervantes, Literature, and the Discourse of Politics (Toronto, Buffalo \& London: Toronto University Press, 2012), in particular chapter 8, "Civil Society, Virtue and the Pursuit of Happiness", 197-235)

${ }^{56}$ See Anthony J. Cascardi, "Gracián and the Authority of Taste", in Ideologies of History in the Spanish Golden Age. (University Park, Pennsylvania: The Pennsylvania State University Press, 1997), 133-159, in particular 136-38. 
them. The sunne $\&$ moone, fire and water are profitable, \& yet common: the Philosopher saith, Bonum quò communius, è̀ melius: good the commoner it is, the better it is.: if it bee true in philosophie, it is true in diuinity, \& therfore S. Paul wisheth that all men were learned as hee was, and that all men could speak with diuers tongues as he did, \& c. I would that these men which think they haue S. Paules learning, had S. Paules zeale (so it were according to knowledge) to seeke other mens good and not their own; for now marchants do not monopolize the goods of a cetie more then these do appropriate vnto themselues the learning of whole vniuersities, \& when they haue it, what do they with it, but keep it vnto themselves. Because I wold not be of this odious sect of men (most courteous \& Christian reader) I haue at vacant times translated according to that measure of knowledge which God hath giuen me, both this book and some others, as the historie of the lesuits, \& Moral Philosophy of the Stoickes, which with permission of my superiors, I mean shortly to publish, if God will, and health permit me so to do. ${ }^{57}$

This emphasis upon communication of knowledge and information exchange, upon the moral lessons that should be shared and 'made common' as 'communicable goods' pervades, as I suggested in the opening paragraph of this chapter, paratexts in this period, and it is also frequently used to justify less than exemplary texts which were nevertheless in large demand. In the preface to Lazarillo de Tormes, its autobiographical narrator appeals to the discerning, adiaphoric reader through the authority of Pliny and Horace in order to justify the narrative he is about to unfold: the life of a rogue who is far from being a model of good behaviour. But even this should be shared, says he, for "no thing should be destroyed or left to waste as evil... but should instead be communicated among all, above all if this is proffered without prejudice and with the potential of extracting some fruit from it." 58

David Summers has provided a comprehensive account of the inherent natural judgement - which combines both judgment of sense and judgement of reason - that paratexts wished for in their intended readers. More importantly, Summers also spells out its proximity to the consensual norm that contemplates common usage, and common language as the best parameters for a proper style in the articulation of shared, conversational knowledge, (i.e., common sense) founded upon Naturalism, and also as a prelude to the Enlightened theory of taste. $^{59}$ Summers' conclusions in particular suggest the aesthetic and political evolution of the concepts of common language and common sense, which would

\footnotetext{
57 "The Translatour to the courteous and Christian Reader", in A Commentary Vpon the Canticle of Canticles, Written first in Italian by Antonio Brucioli, and now translated into English by Th. Iames fellow of New colledge in Oxford, (London: Printed by R. F[ield] for Tho. Man, 1598, USTC: 513634$),[* 8 \mathrm{r}]-[* 8 \mathrm{v}]$

58 “... ninguna cosa se debría romper ni echar a mal... sino que a todos se comunicase, mayormente siendo sin perjuicio y pudiendo sacar della algún fructo" Lazarillo de Tormes, ed. Francisco Rico (Madrid: Real Academia Española, 2011) 3-6.

${ }^{59}$ Summers, 311-334.
} 
bear fruit in the political prose of Thomas Paine, the critical journalism of Doctor Johnson and Joseph Addison, or the poetics of William Wordsworth. ${ }^{60}$ In his Life of the English Poets ("Gray", 1779-1781) Samuel Johnson famously proclaimed that "I rejoyce to concur with the common reader, for by the common sense of readers uncorrupted with literary prejudices, after all the refinements of subtlety and the dogmatism of learning, must be finally decided all claim to poetical honors". ${ }^{61}$ Johnson's opinion epitomizes the culmination of a process that had been long in the making.

${ }^{60}$ Summers, 333-334

${ }^{61}$ Samuel Johnson, The Lives of the Poets. A Selection (Ed. by R. Lonsdale, selected and with an introduction by J. Mullan. Oxford, UK: Oxford University Press, 2009), 461. 